\title{
Chemical Composition of the Mantle
}

\author{
Don L. Anderson \\ Seismological Laboratory, California Institute of Technology
}

\begin{abstract}
The composition of primitive mantle (54 elements) is estimated by a mass balance approach that does not make a priori assignments of basalt:peridotite ratios or LIL contents of these components. It is also not necessary to assume that such ratios as $\mathrm{Rb} / \mathrm{Sr}$ and $\mathrm{K} / \mathrm{U}$ are the same as in the crust. Primitive upper mantle is treated as a four-component system: crust, peridotite, LIL-depleted basalt (MORB), and an LIL-enriched component. These are combined to give chondritic ratios of the oxyphile refractory trace elements. The composition of the whole mantle is estimated by requiring chondritic ratios of the major elements as well. In this way one can estimate the volatile and siderophile content of the mantle. The primitive mantle has $\mathrm{K}=152 \mathrm{ppm}, \mathrm{U}=0.020 \mathrm{ppm}, \mathrm{Th}=0.078$ $\mathrm{ppm}, \mathrm{K} / \mathrm{U}=7724$, and $\mathrm{Rb} / \mathrm{Sr}=0.025$. The ratios are significantly less than previous estimates. The inferred steady state heat flow, $0.9 \mu \mathrm{cal} / \mathrm{cm}^{2} \mathrm{~s}$, implies a substantial contribution of cooling to the observed heat flow. The crust and upper mantle may contain most of the terrestrial inventory of the incompatible elements, including $\mathrm{K}, \mathrm{U}$, and $\mathrm{Th}$. There is no evidence that the chalcophiles are strongly partitioned into the core.
\end{abstract}

\section{Introduction}

The chemical composition of the mantle is one of the most important yet elusive properties of our planet. Previous attempts to estimate mantle composition fall into two broad categories:

1. Cosmochemical. Meteorites or mixtures of meteoritic material are the basic building blocks, and mixing ratios are adjusted to satisfy such constraints as core size, heat flow, and crustal ratios of certain elements. The most recent result is the six-component model of Morgan and Anders [1980]. Unfortunately, heat flow cannot be used to constrain the abundance of $U$ and the other refractory elements, because of the unknown contribution of cooling to observed heat flow. Also, $\mathrm{K} / \mathrm{U}$ and $\mathrm{Tl} / \mathrm{U}$ of the earth are assumed, and these ratios control the content of all the other volatiles. Cosmochemical models constrain the bulk chemistry of the earth rather than that of the mantle alone.

2. Petrological. Since basalts represent melts, and peridotites are thought to be residues, some mixture should approximate the composition of the upper mantle. With only two components [e.g., Ringwood and Kesson, 1977] this approach does not yield chondritic ratios for many key elements, most notably $\mathrm{Si} / \mathrm{Mg}$. The incompatible elements are generally not treated. The silicon depletion is rationalized by invoking siderophile or volatile characteristics for this element [Ringwood, 1975]. An alternate approach is to search for the most 'primitive' (i.e., chondritic ratios of the refractory elements) ultramafic rock and attribute its composition to the whole mantle [Jagoutz et al., 1979; Wänke, 1981]. Unfortunately, even the most 'primitive' ultramafic nodule (a spinel lherzolite in this case) is depleted in many of the trace elements and has nonchondritic LREE/HREE ratios. In constructing a model for the mantle from these nodules, $\mathrm{Sr}, \mathrm{Ba}$, and $\mathrm{U}$ are arbitrarily increased to have chondritic ratios with other refractories [Wänke, 1981].

Copyright 1983 by the American Geophysical Union.

Paper number 3B5019.

0148-0227|831003B-5019\$05.00
Obviously, this approach cannot yield estimates of such key ratios as $\mathrm{K} / \mathrm{U}, \mathrm{Rb} / \mathrm{Sr}, \mathrm{U} / \mathrm{Th}$, and $\mathrm{U} / \mathrm{Pb}$.

Both approaches utilize terrestrial and meteoritic data. The common theme is that the earth should have an unfractionated chondritic pattern of the refractory elements. This is justified by the observation that these elements occur in roughly constant proportions in the various meteorite classes. This has led to the generally accepted hypothesis that the refractory elements do not suffer any preaccretional fractionation. This can be used as a formal a priori constant in geochemical modeling of the composition of the earth.

Once they are in a planet, the refractories become fractionated by a variety of processes. The refractory siderophiles enter the core, the compatible refractories are retained in mantle silicates, and the incompatible refractories preferentially enter melts and the crust.

The volatile elements are fractionated by preaccretional processes, and they exhibit a wide range in meteorites. It is therefore difficult to estimate the volatile content of the earth or to obtain estimates of such key ratios as $\mathrm{K} / \mathrm{U}$, $\mathrm{Rb} / \mathrm{Sr}, \mathrm{Pb} / \mathrm{U}$, etc. It is often assumed [e.g., Ringwood and Kesson, 1977; Morgan and Anders, 1980] that volatile/refractory ratios of this type are the same in the primitive mantle as they are in the continental crust. The crust, of course, is just one repository of the incompatible elements and is less than $0.6 \%$ of the mass of the mantle. The validity of this assumption is therefore not obvious and needs to be tested by an independent approach. This is one motivation for the present paper.

\section{Components}

The view that there is a single primitive mantle magma type that leaves behind a single depleted peridotite, the essence of the pyrolite model, is clearly oversimplified. There is increasing evidence that ophiolitic peridotites are not simply related to the overlying basalts [e.g., Green et al., 1979]. Isotopic data on basalts and nodules show that there are at least two major mantle reservoirs [Gast, 1972; DePaolo and Wasserburg, 1979; Menzies and Murthy, 


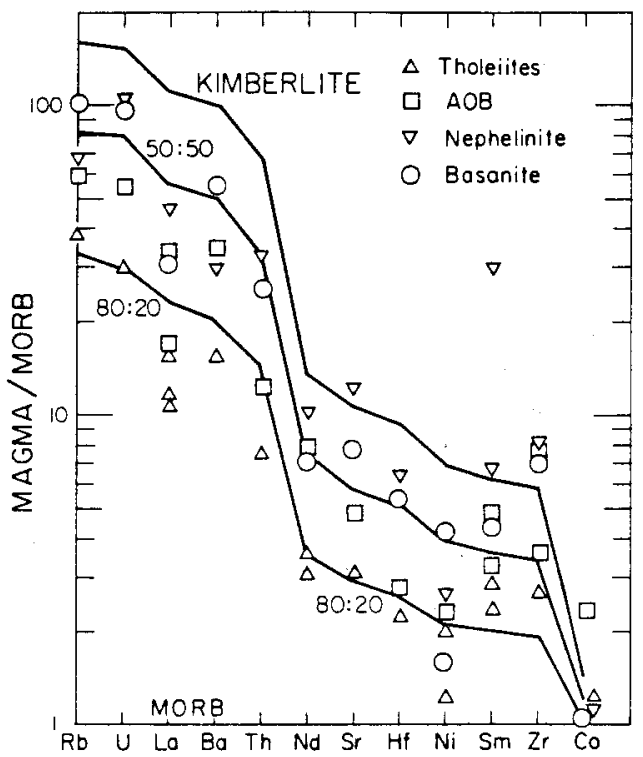

Fig. 1. Trace element contents of kimberlite, MORB, and mixtures compared with compositions of various basaltic magma types.

1980; Basu and Tatsumoto, 19801. The identification of an LIL and isotopically enriched component in ocean island tholeiites and alkali olivine basalts [e.g., Anderson, 1983] also indicates the presence of a component that is not adequately accounted for in the single mantle reservoir models. We subsequently refer to this enriched component as Q (see Appendix 1).

The use of basalts, ultramafic rocks, and continental crust as three components of primitive mantle is conventional. The assumption that the crust and depleted mantle are strictly complementary and are together equivalent to the bulk earth, however, is not consistent with isotopic results [McCulloch et al., 1982]. Basalts cover a broad compositional range, from LIL-poor to LIL-rich (Figure 1). 'Large-ion-lithophile' (LIL) is commonly, although loosely, used to refer to elements (including small high-charge elements!) that do not substitute readily for $\mathrm{Mg}$ or $\mathrm{Fe}$ and are therefore excluded from olivine and orthopyroxene. Some LIL are relatively compatible in garnet and clinopyroxene and have high concentrations in MORB, a depleted magma. Anderson [1982 $b$ ] proposed that most mantle magmas are composed of a depleted MORB component and an enriched component with high $\mathrm{K}$, LIL, ${ }^{87} \mathrm{Sr} /{ }^{86} \mathrm{Sr}$, ${ }^{144} \mathrm{Nd} /{ }^{143} \mathrm{Nd}$, and ${ }^{206} \mathrm{~Pb} /{ }^{204} \mathrm{~Pb}$. Mid-ocean ridge basalts (MORB) represent the most uniform and voluminous magma type and are an end member in LIL concentrations and isotopic ratios. This is one of our components. The MORB source has been depleted by removal of a component that must be rich in LIL but relatively poor in $\mathrm{Na}$ and the ga and cpx compatible elements such as $\mathrm{Al}, \mathrm{Ca}, \mathrm{Yb}$, $\mathrm{Lu}$, and Sc. Kimberlitic magmas have the required complementary relationship to MORB, and are adopted as the $\mathrm{Q}$ component. Peridotites are the main reservoirs for elements such as $\mathrm{Mg}, \mathrm{Cr}, \mathrm{Co}, \mathrm{Ni}$, Os, and Ir. The continental crust is an important reservoir of $\mathrm{K}, \mathrm{Rb}, \mathrm{Ba}, \mathrm{La}, \mathrm{U}$, and $\mathrm{Th}$. Thus each of these components plays an essential role in determining the overall chemistry of the mantle. It is conventional to adopt a single lherzolite or harzburgite as the dominant silicate portion of the mantle. An orthopyroxene-rich component is also present in the mantle and is required if the $\mathrm{Mg} / \mathrm{Si}$ and $\mathrm{Ca} / \mathrm{Al}$ ratios of the earth are to be chondritic.

Figure 2 shows representative compositions of kimberlite, crust, MORB, and ultramafic rock. For many refractory elements, kimberlite and crust have a similar enrichment pattern. However, the volatile/refractory ratios are quite different, as are ratios involving $\mathrm{Sr}, \mathrm{Hf}, \mathrm{Ti}, \mathrm{Li}, \mathrm{Y}, \mathrm{Yb}$, and $\mathrm{Lu}$. Kimberlite and MORB patterns are nearly mirror images for the refractory elements, but this is only approximately true for MORB and crust, especially for the HREE and the small ion-high charge elements. MORB and kimberlite also represent extremes in their $\mathrm{Sr}$ and $\mathrm{Nd}$ isotopic compositions [McCulloch et al., 1983].

An important development in recent years has been the recognition of an LIL-enriched 'metasomatic' component in the mantle. The most extreme magmas from the mantle (high LIL, high LREE/HREE, high ${ }^{87} \mathrm{Sr} /{ }^{86} \mathrm{Sr}$, low ${ }^{143} \mathrm{Nd} /{ }^{144} \mathrm{Nd}$ ) are kimberlites and lamproites [McCulloch et al., 1983]. When mixed with a depleted magma (MORB), the resulting blend can have apparently paradoxical geochemical properties. For example, the hybrid magma can have such high $\mathrm{La} / \mathrm{Yb}, \mathrm{Rb} / \mathrm{Sr}$, and ${ }^{206} \mathrm{~Pb} /{ }^{204} \mathrm{~Pb}$ ratios that derivation from an enriched source is indicated, but the ${ }^{143} \mathrm{Nd} /{ }^{144} \mathrm{Nd}$ and ${ }^{87} \mathrm{Sr} /{ }^{86} \mathrm{Sr}$ ratios imply derivation from an ancient depleted reservoir [Anderson, 1982a]. These characteristics of a hybrid magma are a result of the mixing relations, which depend not only on the ratios of the end members but also on the relative concentrations of elements in the end members; these concentrations control the curvature, or convexity, of the mixing hyperboles. Alkali basalts, for example, can be modeled as mixtures of MORB, or fractionated MORB, as the depleted component and kimberlite as the enriched component (Figure 1). Depending on the degree of crystal fractionation and the mixing ratios, the mixtures can appear to come from ancient depleted

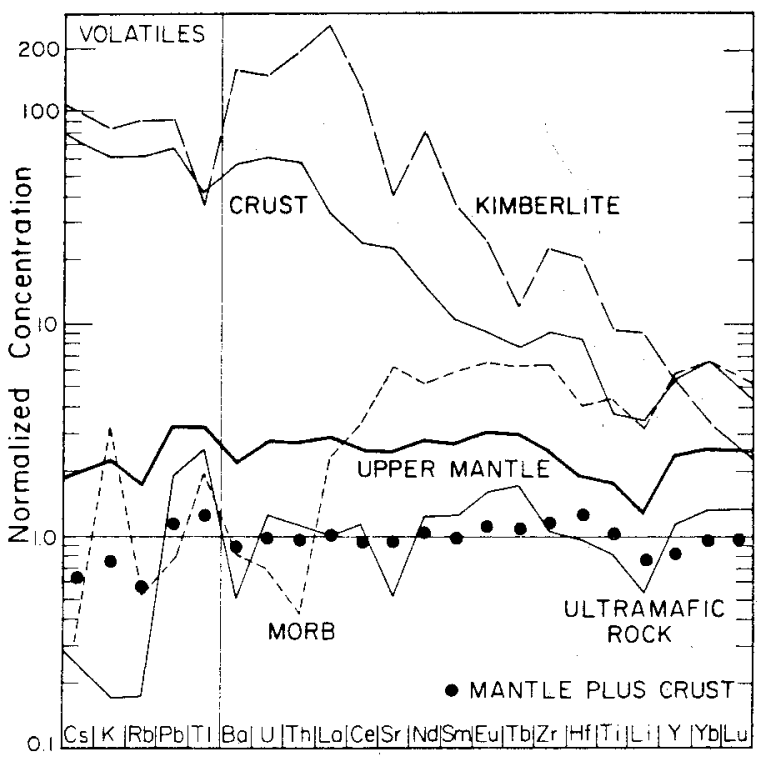

Fig. 2. Lithophile elements in UMR, MORB, crust, and kimberlite normalized to $1.48 \mathrm{x}$ M\&A. Derived values for upper mantle and primitive mantle are also shown. 
reservoirs, ancient enriched reservoirs, 'primitive' reservoirs, or a recently metasomatized reservoir.

Figure 3 shows the effect of crystal fractionation and mixing on the ${ }^{143} \mathrm{Nd} /{ }^{144} \mathrm{Nd},{ }^{87} \mathrm{Sr} /{ }^{36} \mathrm{Sr}$ relation, the "mantle array.' Many magmas can be modeled as mixtures from two isotopically and LIL distinct reservoirs. The spread of observed values suggests that MORB and kimberlite are themselves mixtures.

The possible complementarity of MORB and kimberlite is also illustrated in Figure 4. The ratio MORB/KIMB is bracketed by the partition coefficients for clinopyroxene and garnet, indicating that the MORB source can be formed by removal of a kimberlitic fluid from a clinopyroxene- and garnet-rich reservoir; i.e., MORB and KIMB may be related by solid-liquid equilibrium. Thus we have several reasons for adopting kimberlite as the enriched component of the mantle (see also McCulloch et al. [1983]; Anderson [1981, 1982b, 1983]).

For our present purposes it is important to have a complete inventory of possible components of primitive mantle, but it is not necessary to have a detailed evolutionary model in mind. The above results indicate, however, that the depleted, or MORB, reservoir can be formed by removal of a kimberlitic, as well as a crustal, component from a clinopyroxene- and garnet-rich region of the mantle. This LILrich fraction enters the continental crust and metasomatizes the shallow mantle. Later melting episodes in the depleted reservoir provide depleted (MORB) basalts, which interact with melts from the shallow enriched mantle to form the spectrum of basalts observed. Thus the large number of

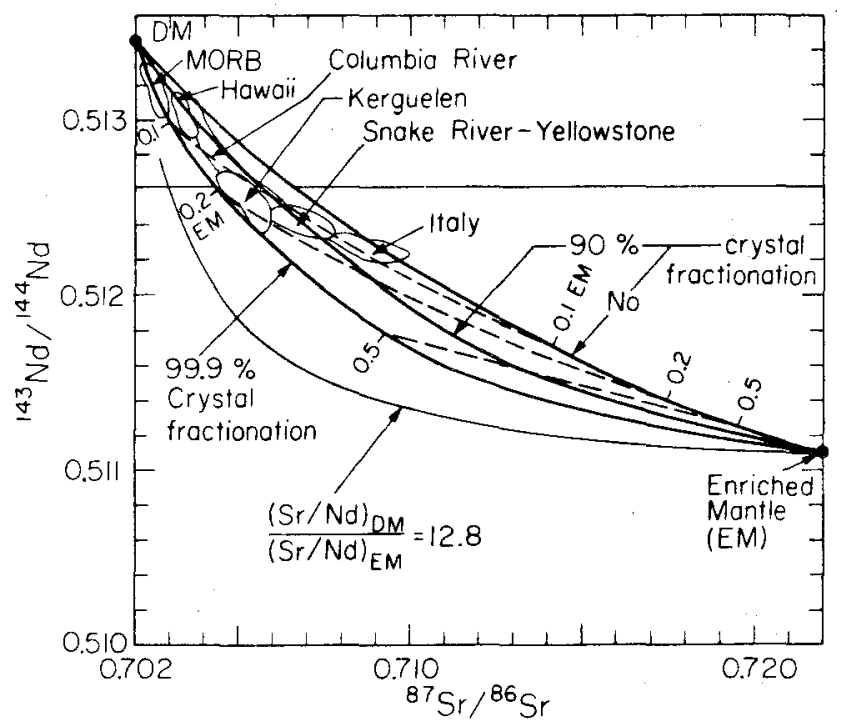

Fig. 3. ${ }^{143} \mathrm{Nd} /{ }^{144} \mathrm{Nd}$ versus ${ }^{87} \mathrm{Sr} /{ }^{86} \mathrm{Sr}$ showing effects of mixing between depleted mantle (DM) and enriched mantle (EM). DM is somewhat more depleted than MORB; EM is somewhat more enriched than kimberlite $\left({ }^{87} \mathrm{Sr} /{ }^{86} \mathrm{Sr}<.7124\right)$ and lamproite $\left({ }^{87} \mathrm{Sr} /{ }^{86} \mathrm{Sr}<.7186\right)$, similar to values adopted by McCulloch et al. [1983]. Crystal fractionation involved removal of equal parts garnet and clinopyroxene from a MORB-like melt from DM, thereby increasing the $(\mathrm{Sr} / \mathrm{Nd})_{\mathrm{DM}} /(\mathrm{Sr} / \mathrm{Nd})_{\mathrm{EM}}$ ratio. The field of mantle basalts is encompassed by blends consisting of fractionated depleted basalts (0-99.9 crystal fractionation) mixed with 0 to $20 \%$ enriched mantle. Data from Menzies et al. [1983], Carlson et al. [1981], Chen and Frey [1983], and Hawkesworth and Vollmer [1979].

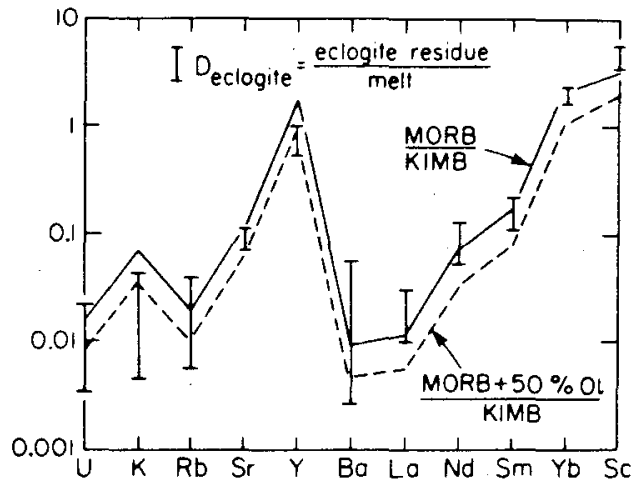

Fig. 4. Ratio of concentrations in MORB and kimberlite (KIMB). Vertical bars: solid/liquid partition coefficients for garnet plus clinopyroxene [Anderson, 1983].

potential candidates for the basaltic fraction of the earth's mantle has been reduced to two components. MORB, although formed at high pressure, fractionates at low pressure and interacts with the shallow enriched mantle to form nephelinites, melilitites, etc. Kimberlites, carbonatites, and lamproites, in this scheme, are derived from a reservoir that is shallower than the MORB reservoir.

The task before us is to estimate the composition and relative abundance of each component. We seek a linear combination that gives chondritic ratios for the refractory elements. We then have estimates of the volatile and siderophile content of the primitive mantle including such key ratios as $\mathrm{Rb} / \mathrm{Sr}, \mathrm{K} / \mathrm{U}$, and $\mathrm{U} / \mathrm{Pb}$. In essence, we replace the five basic building blocks of mantle chemistry (ol, opx, $\mathrm{cpx}$, ga, and Q, or their high- and low-pressure equivalents) with four composites: peridotite (ol $\pm \mathrm{opx}$ ), orthopyroxenite (opx $\pm \mathrm{ol}$ ), basalt (cpx $+\mathrm{ga})$, and $\mathrm{Q}$. In practice, we use two different ultramafic rocks (UMR and OPX) with different ol/opx ratios to decouple the ol + opx contributions. The chemistry of the components (MORB, UMR, KIMB, OPX, and crust) are given in Tables 1 and 2 . Details and references are given in Appendix 1.

\section{Mixing Relations}

We have measurements of $m$ elements in $n$ components where $m>>n$. We wish to find the weight fraction $x_{j}$ of each component, given the concentration $C_{i j}$ of the $j$ th element in the $i$ th component, that yields chondritic ratios of the refractory oxyphile elements. In matrix form

$$
\mathrm{C}_{\mathrm{ij}} \mathrm{x}_{\mathrm{j}}=\mathrm{kC}_{\mathrm{j}}
$$

where $C_{j}$ is the chondritic abundance of element $j$ and $k$ is a dilution or enrichment factor, which is also to be determined. The least squares solution is

$$
x_{j} / k=\left(C^{T} C\right)^{-1} C^{T} C_{j}
$$

with the constraints

$$
\sum \mathbf{x}_{\mathrm{j}}=1 \quad \text { and } \quad \mathrm{k}=\text { constant }
$$


TABLE 1. Chemical Composition of Mantle Components

\begin{tabular}{|c|c|c|c|c|c|c|c|}
\hline & MORB & $\begin{array}{r}\text { ULTRAMAFIC } \\
\text { ROCKS } \\
\end{array}$ & KIMB & CRUST & PICRITE & OPX & $\begin{array}{r}\text { MORGAN \& } \\
\text { ANDERS } \\
\end{array}$ \\
\hline $\mathrm{Li}$ & 9 & 1.5 & 25 & 10 & 7 & 1.5 & 1.85 \\
\hline F & 289 & 7 & 1900 & 625 & 219 & & 14 \\
\hline $\mathrm{Na}$ & 15900 & 2420 & 2030 & 26000 & 12530 & & 1250 \\
\hline Mg & 5.89 & 23.10 & 16.00 & 2.11 & 10.19 & 21.00 & 13.90 \\
\hline $\mathrm{Al}$ & 8.48 & 2.00 & 1.89 & 9.50 & 6.86 & 1.21 & 1.41 \\
\hline $\mathrm{Si}$ & 23.20 & 21.80 & 14.70 & 27.10 & 22.85 & 22.60 & 15.12 \\
\hline $\mathbf{P}$ & 390 & 61 & 3880 & 1050 & 308 & & 1920 \\
\hline $\mathbf{S}$ & 600 & 8 & 2000 & 260 & 452 & & 14600 \\
\hline $\mathrm{Cl}$ & 23 & 1 & 300 & 1074 & 17 & & 20 \\
\hline $\mathrm{K}$ & 660 & 35 & 17600 & 12500 & 504 & 10 & 135 \\
\hline $\mathrm{Ca}$ & 8.48 & 2.40 & 7.04 & 5.36 & 6.96 & 1.32 & 1.54 \\
\hline Sc & 37.3 & 17 & 15 & 30 & 32 & 12 & 9.6 \\
\hline $\mathrm{Ti}$ & 5500 & 1000 & 11800 & 4800 & 4375 & 800 & 820 \\
\hline V & 210 & 77 & 120 & 175 & 177 & 60 & 82 \\
\hline $\mathrm{Cr}$ & 441 & 2500 & 1100 & 55 & 956 & 2500 & 4120 \\
\hline Mn & 1080 & 1010 & 1160 & 1100 & 1063 & 1010 & 750 \\
\hline $\mathrm{Fe}$ & 6.52 & 6.08 & 7.16 & 5.83 & 6.41 & 6.08 & 32.07 \\
\hline Co & 53 & 105 & 77 & 25 & 66 & 105 & 840 \\
\hline $\mathrm{Ni}$ & 152 & 2110 & 1050 & 20 & 642 & 2110 & 18200 \\
\hline $\mathrm{Cu}$ & 77 & 15 & 80 & 60 & 62 & 30 & 31 \\
\hline $\mathrm{Zn}$ & 74 & 60 & 80 & 52 & 71 & 20 & 74 \\
\hline $\mathrm{Ga}$ & 18 & 4 & 10 & 18 & 14 & 3 & 3 \\
\hline $\mathrm{Ge}$ & 1.5 & 1.1 & 0.5 & 1.5 & 1.4 & 1.1 & 7.6 \\
\hline $\mathrm{Se}$ & 0.181 & 0.02 & 0.15 & 0.05 & 0.14 & 0.006 & 9.6 \\
\hline $\mathrm{Rb}$ & 0.36 & 0.12 & 65 & 42 & 0.30 & 0.04 & 0.458 \\
\hline $\mathrm{Sr}$ & 110 & 8.9 & 707 & 400 & 85 & 4.5 & 11.6 \\
\hline Y & 23 & 4.6 & 22 & 22 & 18 & 0.023 & 2.62 \\
\hline $\mathrm{Zr}$ & 70 & 11 & 250 & 100 & 55 & 5.5 & 7.2 \\
\hline $\mathrm{Nb}$ & 3.3 & 0.9 & 110 & 11 & 2.7 & 0.45 & 0.5 \\
\hline $\mathrm{Ag}$ & 0.019 & 0.0025 & & 0.07 & 0.015 & 0.001 & 0.044 \\
\hline $\mathrm{Cd}$ & 0.129 & 0.0255 & 0.07 & 0.2 & 0.103 & 0.01 & 0.016 \\
\hline In & 0.072 & 0.002 & 0.1 & 0.1 & 0.055 & & 0.002 \\
\hline $\mathrm{Sn}$ & 1.36 & 0.52 & 15 & 2 & 1.15 & 0.52 & 0.39 \\
\hline Cs & 0.007 & 0.006 & 2.3 & 1.7 & 0.01 & 0.002 & 0.0153 \\
\hline $\mathbf{B a}$ & 5 & 3 & 1000 & 350 & 4.50 & 2 & 4 \\
\hline $\mathbf{L a}$ & 1.38 & 0.57 & 150 & 19 & 1.18 & 0.044 & 0.379 \\
\hline $\mathrm{Ce}$ & 5.2 & 1.71 & 200 & 38 & 4.33 & 0.096 & 1.01 \\
\hline Nd & 5.61 & 1.31 & 85 & 16 & 4.54 & 0.036 & 0.69 \\
\hline $\mathrm{Sm}$ & 2.08 & 0.43 & 13 & 3.7 & 1.67 & 0.009 & 0.2275 \\
\hline $\mathrm{Eu}$ & 0.81 & 0.19 & 3 & 1.1 & 0.66 & 0.0017 & 0.079 \\
\hline $\mathrm{Tb}$ & 0.52 & 0.14 & 1 & 0.64 & 0.43 & 0.0017 & 0.054 \\
\hline $\mathrm{Yb}$ & 2.11 & 0.46 & 1.2 & 2.2 & 1.70 & 0.0198 & 0.229 \\
\hline $\mathrm{Lu}$ & 0.34 & 0.079 & 0.16 & 0.3 & 0.27 & 0.0072 & 0.039 \\
\hline Hf & 1.4 & 0.34 & 7 & 3 & 1.14 & 0.17 & 0.23 \\
\hline Тa & 0.1 & 0.03 & 9 & 2 & 0.08 & & 0.023 \\
\hline $\operatorname{Re}$ & 1.1 & 0.23 & 1 & 1 & 0.88 & 0.08 & 60 \\
\hline Os & 0.04 & 3.1 & 3.5 & 5 & 0.81 & 3.1 & 880 \\
\hline Ir & 0.0011 & 3.2 & 7 & 1 & 0.80 & 3.2 & 840 \\
\hline $\mathrm{Au}$ & 0.34 & 0.49 & 4 & 4 & 0.38 & 0.49 & 257 \\
\hline $\mathrm{Tl}$ & 0.01 & 0.02 & 0.22 & 0.25 & 0.01 & & 0.00386 \\
\hline $\mathrm{Pb}$ & 0.08 & 0.2 & 10 & 7 & 0.11 & & 0.068 \\
\hline $\mathrm{Bi}$ & 0.007 & 0.005 & 0.03 & 0.2 & 0.01 & & 0.00294 \\
\hline $\mathrm{Th}$ & 0.035 & 0.094 & 16 & 4.8 & 0.05 & & 0.0541 \\
\hline$\underline{U}$ & 0.014 & 0.026 & 3.1 & 1.25 & 0.02 & & 0.0135 \\
\hline
\end{tabular}


TABLE 2. Chemical Composition of Mantle

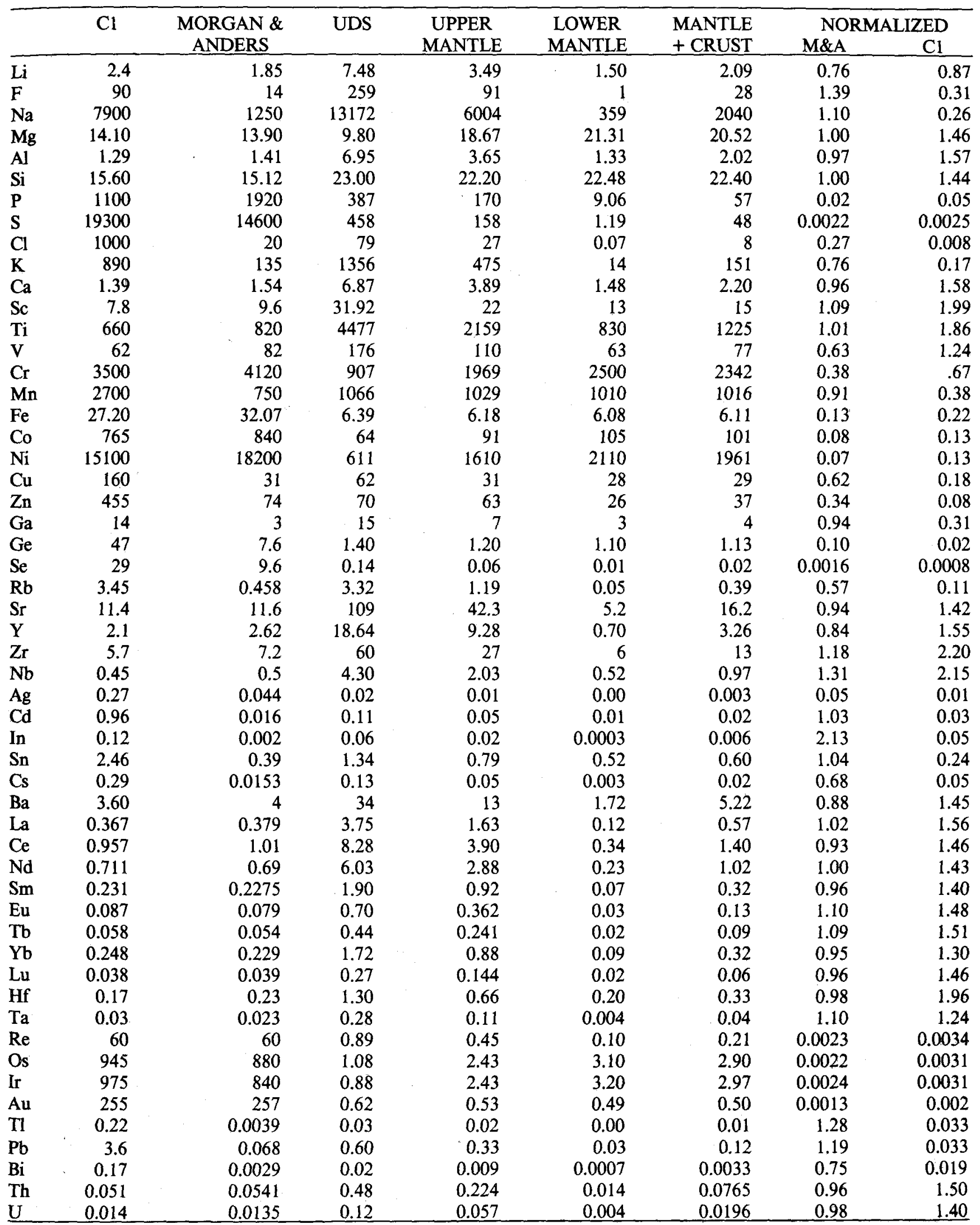


TABLE 3. Elemental Ratios

\begin{tabular}{lccccccc}
\hline MORB & $\begin{array}{c}\text { ULTRAMAFIC } \\
\text { ROCKS }\end{array}$ & KIMB & CRUST & PICRITE & OPX & $\begin{array}{c}\text { MORGAN \& } \\
\text { ANDERS }\end{array}$ \\
\hline $\mathrm{Rb} / \mathrm{Sr}$ & 0.0033 & 0.0135 & 0.0919 & 0.105 & 0.0035 & 0.0089 & 0.039 \\
$\mathrm{~K} / \mathrm{U}$ & 47143 & 1346 & 5677 & 10000 & 29632 & & 10000 \\
$\mathrm{Sm} / \mathrm{Nd}$ & 0.371 & 0.328 & 0.153 & 0.231 & 0.368 & 0.25 & 0.3297 \\
$\mathrm{Th} / \mathrm{U}$ & 2.50 & 3.62 & 5.16 & 3.84 & 2.94 & & 4.01 \\
$\mathrm{U} / \mathrm{Pb}$ & 0.18 & 0.13 & 0.31 & 0.18 & 0.15 & & 0.20 \\
$\mathrm{La} / \mathrm{Yb}$ & 0.65 & 1.24 & 125 & 8.64 & 0.69 & 2.22 & 1.66 \\
$\mathrm{~K} / \mathrm{Na}$ & 0.84 & 0.01 & 8.67 & 0.48 & 0.04 & & 0.11 \\
$\mathrm{Mg} / \mathrm{Si}$ & 0.25 & 1.06 & 1.09 & 0.08 & 0.45 & 0.93 & 0.92 \\
$\mathrm{Ca} / \mathrm{Al}$ & 1.00 & 1.20 & 3.72 & 0.56 & 1.01 & 1.09 & 1.09 \\
$\mathrm{Yb} / \mathrm{Sc}$ & 0.057 & 0.027 & 0.08 & 0.073 & 0.053 & 0.0017 & .0239 \\
$\mathrm{Ce} / \mathrm{Nd}$ & 0.93 & 1.31 & 2.35 & 2.38 & 0.95 & .2 .67 & 1.46 \\
$\mathrm{Eu} / \mathrm{Nd}$ & 0.14 & 0.15 & 0.04 & 0.07 & 0.14 & 0.05 & 0.11 \\
$\mathrm{Yb} / \mathrm{Lu}$ & 6.21 & 5.82 & 7.50 & 7.33 & 6.18 & 2.75 & 5.87 \\
$\mathrm{Sr} / \mathrm{Ba}$ & 22.00 & 2.97 & 1.18 & 1.14 & 18.83 & 3.00 & 2.90 \\
$\mathrm{U} / \mathrm{La}$ & 0.01 & 0.46 & 0.021 & 0.066 & 0.014 & & 0.036 \\
\hline
\end{tabular}

When $x_{j}$ and $k$ are found, (1) gives the mantle concentrations of the volatile and siderophile elements, elements not used in the inversion. $C^{T}$ is the transpose of $C$.

The mixing ratios found from (2) and (3) are UMR (32.6\%), OPX (59.8\%), MORB (6.7\%), CRUST (0.555\%), and Q $(0.11 \%)$. This is a model composition for primitive mantle; i.e., mantle plus crust. The $\mathrm{Q}$ component is equivalent to a global layer $3.6 \mathrm{~km}$ thick. This solution is based on 18 refractory elements and, relative to carbonaceous chondrite $(\mathrm{C} 1)$ abundances, $k=1.46 \pm 0.09$. The result is given in Table 3 under 'Mantle plus crust.' Concentrations normalized to $\mathrm{Cl}$ are also given in Table 3. Note that the high-charge, small ionic radius elements, $\mathrm{Sc}, \mathrm{Ti}, \mathrm{Zr}$, $\mathrm{Nb}$, and $\mathrm{Hf}$, have relatively high $\mathrm{Cl}$ normalized ratios and appear to behave differently from the other refractories. Taking all the refractory oxyphile elements into account $(23$ elements), the $\mathrm{C} 1$ normalized enrichment of the refractory elements in the mantle plus crust is $1.59 \pm 0.26$. If $\mathrm{Fe}, \mathrm{S}$, $\mathrm{Ni}, \mathrm{Co}, \mathrm{P}$, and $\mathrm{O}$ are removed from $\mathrm{Cl}$ to form an earthsize core, the remaining silicate fraction will be enriched in the oxyphile elements by a factor of 1.48 relative to the starting $\mathrm{Cl}$ composition. This factor can be compared with the values for $k$ determined from the inversions. Thus it appears that the earth can be chondritic in major and refractory element chemistry if an appreciable amount of oxygen has entered the core.

We also compare our results in Tables 3 and 4 and Figure 2 with Morgan and Anders' [1980, hereafter M\&A] cosmochemically based model. This model can be viewed as providing a first order correction for volatile/refractory fractionation and inhomogeneous accretion. Rather than treating each element separately, as in the present study, M\&A estimate abundances of groups of elements, e.g., refractories, volatiles, etc. There is strong support for unfractionated behavior of refractories prior to accretion, but the idea that the volatile elements are also unfractionated, albeit depleted, needs to be tested.

\section{Discussion}

In the pyrolite models, it is assumed that one knows the average compositions of the basaltic and ultramafic com- ponents of the mantle. These are mixed in somewhat arbitrary proportions and the results are compared a posteriori with chondritic abundances. Tholeiitic basalts are thought to represent the largest degree of partial melting among common basalt types and most nearly reflect the trace element chemistry of their mantle source. Tholeiites, however, range in composition from depleted mid-ocean ridge basalts to enriched ocean island (OIB) and continental flood basalts (CFB). The present paper takes advantage of the fact that enriched basalts (alkali-olivine basalts, OIB, CFB) can be modeled as mixtures of MORB and a kimberlite-like component, i.e., basalt $=M O R B+Q$ (Figure 1). In a later paper we show that the LIL and isotopic compositions of OIB and CFB can be satisfied by a mixture of $Q$ and fractionated MORB. This is more complicated than simple binary mixing but, nevertheless, $Q$ or kimberlite is a component of the mix.

Likewise, ultramafic rocks from the mantle have a large compositional range. Some appear to be crystalline residues after basalt extraction, some appear to be cumulates, and others appear to have been secondarily enriched in incompatible elements (metasomatized). Some ultramafic rocks have high $\mathrm{Al}_{2} \mathrm{O}_{3}$ and $\mathrm{CaO}$ contents and are therefore 'fertile' (i.e., they can yield basalts upon partial melting), but they do not have chondritic ratios of all the refractory elements.

We have, in essence, decomposed the basaltic component of the mantle into a depleted (MORB) and LILenriched $(Q)$ component. These can be combined and compared with the basaltic component of previous twocomponent models, such as pyrolite, by comparing our 'undepleted basalt' (MORB $+1.5 \%$ KIMB) with the basalts chosen by Ringwood (Hawaiian tholeiite or 'primitive' oceanic tholeiite, KD11 [Kay and Hubbard, 1978]). Thus our undepleted basaltic component (MORB + Q) has $\mathrm{K}=$ $914 \mathrm{ppm}, \mathrm{U}=0.06 \mathrm{ppm}$, and $\mathrm{Th}=0.27 \mathrm{ppm} . \mathrm{KD} 11 \mathrm{has}$, for these elements, $1400,0.152$, and $0.454 \mathrm{ppm}$, respectively, and other incompatible elements are correspondingly high. Refractory ratios such as $\mathrm{U} / \mathrm{Ca}$ and $\mathrm{Th} / \mathrm{Ca}$ for this pyrolite are about $50 \%$ higher than chondritic because of the high LIL content of the chosen basalt. Hawaiian tholeiites, the basis of another pyrolite model [Ringwood, 1975l, have LIL concentrations even higher than KD11. 
One disadvantage of these pyrolite type models is that the final results are controlled by the arbitrary choice of components, including basalt. Indeed, the various pyrolite models differ by an order of magnitude in, for example, the abundance of $\mathrm{K}$.

By and large, there is excellent agreement between our estimate of mantle composition and the M\&A cosmochemical model (Table 3). In the present model, the alkalies $\mathrm{Li}$, $\mathrm{K}, \mathrm{Rb}$, and $\mathrm{Cs}$ are somewhat more depleted, as are volatiles such as $\mathrm{Cl}, \mathrm{V}$, and $\mathrm{Cd}$. The $\mathrm{Rb} / \mathrm{Sr}$ and $\mathrm{K} / \mathrm{U}$ ratios are correspondingly reduced. The elements that are excessively depleted, $\mathrm{P}, \mathrm{S}, \mathrm{Fe}, \mathrm{Co}, \mathrm{Ni}, \mathrm{Ge}, \mathrm{Se}, \mathrm{Ag}, \mathrm{Re}, \mathrm{Os}, \mathrm{Ir}$, and $\mathrm{Au}$, are plausibly interpreted as residing in the core. Note that the chalcophiles are not all depleted. In particular, $\mathrm{Pb}$ is not depleted relative to other volatiles such as $\mathrm{Mn}, \mathrm{F}$, and $\mathrm{Cl}$, which are unlikely to be concentrated in the core, or to the alkali metals. The less volatile chalcophiles ( $\mathrm{Bi}, \mathrm{Cu}, \mathrm{Zn}$ ) are slightly depleted. The most depleted siderophiles and chalcophiles are those that have the highest ionization potential and therefore may have suffered preaccretional sorting in the nebula. There is little support for the conjecture that the chalcophiles are strongly partitioned into the core if we accept the M\&A estimates of terrestrial chalcophile abundances.

Some elements are extraordinarily concentrated into the crust [Gast, 1972]. Our results give, for the percent of the total mantle-plus-crust inventory in the continental crust: $\mathrm{Rb}, 58 \%$; $\mathrm{Cs}, 53 \%$; K, 46\%; $\mathrm{Ba}, 37 \%$; Th and $\mathrm{U}, 35 \%$; $\mathrm{Bi}$, $34 \%$; $\mathrm{Pb}, 32 \%$; $\mathrm{Ta}, 30 \%$; $\mathrm{Cl}, 26 \%$; $\mathrm{La}, 19 \%$; and $\mathrm{Sr}, 13 \%$. In addition, the atmospheric $\mathrm{Ar}^{40}$ content represents $77 \%$ of the total produced by $152 \mathrm{ppm} \mathrm{K}$ over the age of the earth. These results all point toward an extensively differentiated earth and efficient upward concentration of the incompatible trace elements. It is difficult to imagine how these concentrations could be achieved if the bulk of the mantle is still primitive or unfractionated as envisaged by DePaolo and Wasserburg [1979]. If only the upper mantle provides these elements to the crust, one would require more than $100 \%$ removal of $\mathrm{U}, \mathrm{Th}, \mathrm{Bi}, \mathrm{Pb}, \mathrm{Ba}, \mathrm{Ta}, \mathrm{K}, \mathrm{Rb}$, and $\mathrm{Cs}$. More likely, the whole mantle has contributed to crustal and upper mantle abundances, and the lower mantle is depleted in the incompatible elements including $\mathrm{K}, \mathrm{U}$, and Th. This depletion probably occurred during accretion or in early earth history and does not imply present-day communication between the upper and lower mantle. In the following section, we assume that the primitive upper mantle (crust, MORB, Q, and UMR) is the complement of the lower mantle (UMR plus OPX).

\section{Mantle Subdivisions}

The mass balance method gives the average composition of the mantle but makes no statement about how the components are distributed between the upper and lower mantle. If we assume that the only ultramafic component of the upper mantle is UMR, we can estimate the composition of the upper and lower mantles and, as an intermediate step, the composition of the MORB source region prior to extraction of crust and $\mathrm{Q}$. The lower mantle is UMR plus OPX. OPX, the most uncertain and to some extent arbitrary of our components, plays a minor role in the mass balance calculations for the trace refractories and is required mainly to obtain chondritic ratios of $\mathrm{Ca} / \mathrm{Al}$ and $\mathrm{Mg} / \mathrm{Si}$.

Our approach to the upper mantle is similar to the conventional approach in that we consider a basaltic and an ultramafic component. However, instead of making an a priori selection of basalt, we have decomposed it into a depleted (MORB) and an enriched (Q) component. These represent extremes in both LIL contents and isotopic ratios. For example, fresh MORB has ${ }^{87} \mathrm{Sr} /{ }^{86} \mathrm{Sr}$ as low as 0.7023 (Basaltic Volcanism Study Project) and kimberlite has ${ }^{87} \mathrm{Sr} /{ }^{86} \mathrm{Sr}=0.704-0.715$ [Berg and Allsop, 1972; McCulloch et al., 1983]. Alkalic basalts are intermediate in both LIL-contents and isotopic ratios [Batiza and Johnson, 1980; Anderson, 1982a]. The procedure is as follows: The mixing ratios of MORB, crust, and $Q$ are known from our previous results, and these are assumed to be entirely contained in the primitive upper mantle. The absolute sizes of the crustal and upper mantle reservoirs (above $650 \mathrm{~km}$ ) are known, so we know both the relative and the absolute amounts of each component. As an intermediate step, we estimate the composition of a possible picritic parent to MORB. The relation PICRITE $=0.75 \mathrm{MORB}+0.25$ UMR gives the results tabulated under PICR in Table 3.

The mixing ratios that were determined to give a chondritic pattern for the refractory elements yield

$$
\text { UDS - } 0.9355 \text { PICRITE + } 0.0106 Q+0.0559 \text { CRUST }
$$

The composition of this reconstructed undepleted source region is tabulated under UDS in Table 1. The fraction of the crustal component is about 10 times the crust/mantle ratio, so UDS accounts for $10 \%$ of the mantle. Note that our goal of obtaining chondritic ratios of the refractory elements is nearly achieved at this stage for $\mathrm{Sm} / \mathrm{Nd}, \mathrm{Ce} / \mathrm{Nd}$, $\mathrm{Eu} / \mathrm{Nd}, \mathrm{Yb} / \mathrm{Lu}, \mathrm{Sr} / \mathrm{Ba}, \mathrm{U} / \mathrm{La}$, and $\mathrm{Th} / \mathrm{U}$. The remainder of the upper mantle, $30 \%$ of the whole mantle, is assumed to be UMR. This gives the composition tabulated under 'Upper Mantle.' This region contains $23.4 \%$ basalt (MORB), similar to other estimates of upper mantle composition such as pyrolite [Ringwood, 1975]. The resulting upper mantle has refractory element ratios that, in general, are in agreement with chondritic ratios. The $\mathrm{La} / \mathrm{Yb}, \mathrm{Al} / \mathrm{Ca}$, and $\mathrm{Si} / \mathrm{Mg}$ ratios, however, are too high. These are balanced by the lower mantle in the full calculation. The solution for the lower mantle is 0.145 UMR and $0.855 \mathrm{OPX}$, which gives chondritic ratios for $\mathrm{Mg} / \mathrm{Si}$ and $\mathrm{Ca} / \mathrm{Al}$ for the earth as a whole. Note that the lower mantle has a low $\mathrm{La} / \mathrm{Yb}$ ratio, i.e., it is LREE depleted.

Figure 2 shows the concentrations of the lithophile elements in the various components, upper mantle, and mantle-plus-crust, all normalized to the M\&A mantle equivalent concentrations. The refractory elements in the upper mantle have normalized concentrations of about three; this includes the crustal contribution. Since the upper mantle is about one third of the whole mantle, a strongly depleted lower mantle is implied. Critical element ratios are given in Table 4. The last two columns give ratios in 'Mantle plus crust' relative to the two reference models. The refractory/refractory ratios should be near unity, since these are constraints. The volatile/refractory and volatile/volatile ratios are predictions from the model. 


\section{Composition of the Lower Mantle}

Whether the earth is chondritic in major element ratios, as assumed here, or is pyrolitic with a large silicon deficiency depends on the composition of the lower mantle. Seismic data show that the lower mantle has a higher density and bulk modulus than olivine-rich peridotite or pyrolite, whether in a mixed oxide or perovskite-bearing assemblage. The lower mantle is separated from the upper mantle by a sharp discontinuity at about $650 \mathrm{~km}$. The sharpness of the discontinuity and the magnitude of the density and velocity jumps strongly suggest that this is a chemical discontinuity as well as a phase change [Anderson, 1977; Burdick and Anderson, 1975].

There has been considerable controversy regarding the composition of the lower mantle. Ringwood [1975] has advocated a chemically uniform pyrolite mantle with $\mathrm{Mg} / \mathrm{Si}$ $\approx$ 1.5. Anderson and coworkers [e.g., Anderson, 1977; Butler and Anderson, 1978] have shown, however, that the seismic data imply a chondritic or pyroxene-rich lower mantle with $\mathrm{Mg} / \mathrm{Si} \approx 1$. Some early studies based on velocity-density systematics and old earth models inferred high $\mathrm{FeO}$ as well as high $\mathrm{SiO}_{2}$ [e.g., Birch, 1961; Press, 1970; Anderson, 1970]. When modern earth models are used [Davies, 1974; Anderson, 1977; and Butler and Anderson, 1978], FeO enrichment is allowed but not required.

In an attempt to resolve the density discrepancy, Ringwood [1975] suggested that $\mathrm{Mg}_{2} \mathrm{SiO}_{4}$ might transform to $\mathrm{MgSiO}_{3}$ (perovskite) with a density 3 to $7 \%$ greater than the isochemical mixed oxides. This transformation has subsequently been found [Liu, 1974], but the density increase is only $2 \%$ relative to the mixed oxides and the density difference is negligible at high pressure [Anderson, 1977; Yagi et al., 1978]. The pyrolite density discrepancy therefore still remains.

The main seismic evidence for a high $\mathrm{SiO}_{2}$ content for the lower mantle, however, is the high bulk modulus, $\mathrm{K}_{\mathbf{0}}$. Ringwood [1979], following Liebermann et al. [1976], estimates a $\mathrm{K}_{\mathrm{o}}$ for perovskite that is $8 \%$ greater than measurements [Yagi et al., 1979] and concludes that there is 'little doubt' that material of pyrolite composition is capable of explaining the density and seismic distributions throughout most of the lower mantle. A similar conclusion [Watt and O'Connell, 1978] has been withdrawn [Watt and Ahrens, 1982] because it was based on erroneous values for the $K_{0}$ of and an inadvertent use of the linear, rather than the volume, thermal expansion, which led to a $300 \%$ error in a critical temperature correction.

The bulk modulus for $\mathrm{MgSiO}_{3}$ (perovskite) estimated by Liebermann et al. [1976] is greater than their $\mathrm{K}_{\mathrm{o}}$ for stishovite. This rather implausible situation leads directly to Ringwood's conclusion regarding an $\mathrm{MgO}$-rich, i.e., pyrolite, lower mantle. The $\mathrm{K}_{\mathrm{o}}$ of single-crystal stishovite [Weidner et al., 1982] is actually 22\% greater than perovskite, rather than $11 \%$ less as assumed by Ringwood. Liebermann et al. [1976] obtained a $\mathrm{K}_{\mathrm{o}}$ of 2.5 mbar on a porous, cracked specimen of stishovite. This value, used by Ringwood, is $21 \%$ less than measurements on single crystals. These discrepancies are rather serious, since the difference in $K_{o}$ between a pyroxene and olivine lower mantle is only $16 \%$.

When the newer, more accurate data are used, one con- cludes that the density $\left(4.1 \mathrm{~g} / \mathrm{cm}^{3}\right)$ and bulk modulus $(2.6$ mbar) of the lower mantle [Butler and Anderson, 1978] are coincident with perovskite $\left(\rho=4.1 \mathrm{~g} / \mathrm{cm}^{3}, \mathrm{~K}_{\mathrm{o}}=2.6 \mathrm{mbar}\right.$ ). Substantial amounts of $(\mathrm{Mg}, \mathrm{Fe}) \mathrm{O}$, as in the pyrolite models, cannot be tolerated because of the very low $\mathrm{K}_{0}$ of ( $\mathrm{Mg}, \mathrm{Fe}) \mathrm{O}$. Thus the methodology advocated by Ringwood, when implemented with modern data, not only does not resolve the pyrolite discrepancy but instead gives support to the alternate hypothesis of a pyroxene-rich lower mantle with a near chondritic $\mathrm{Mg} / \mathrm{Si}$ ratio. These results, based on physical arguments, agree with the chemical model presented here.

\section{Discussion of Choice of Mantle Components}

In any exercise of this type the choice of components is somewhat arbitrary. The method we use, however, does not require that end members (i.e., olivine, orthopyroxene, clinopyroxene, garnet, primitive depleted basalt, and Q) be used. The components can be viewed as linear combinations of end members and therefore linear inverse techniques can be used to determine the mixing ratios.

Mid-ocean ridge tholeiites are assumed to represent extensive melting of a large depleted reservoir and therefore should represent a good average of the low melting fraction (mainly ga plus cpx) of depleted mantle, including the incompatible elements. These basalts probably provide a better average than could be obtained by using analyses of mantle cpx and ga, since they integrate over a large portion of the mantle.

The ultramafic composition chosen is that of one of the more depleted garnet lherzolite xenoliths studied by Jagoutz et al. [1979], material thought to be relatively 'primitive' or undifferentiated. In fact, if we had chosen a less depleted basalt or a more depleted ultramafic component, the mixing ratios and the amount of $Q$ would change. However, insofar as the LIL-enriched component of basalts and ultramafic rocks is similar to kimberlite, the total composition of the mantle is not sensitive to the choice of the depleted mafic and ultramafic components. In this respect our results are less sensitive to the choice of components than previous petrological models. It is instructive, however, to examine the effects of using different components.

\section{An Alternate Approach}

In an effort to test the stability of our results, we have repeated the inversion, using as before CRUST, MORB, and KIMB as three of our components but replacing UMR and OPX by olivine, orthopyroxene, and clinopyroxene, using analyses from references given in Appendix 1 . The present mantle is therefore viewed as a five-component system involving olivine, orthopyroxene, clinopyroxene, MORB (cpx and ga), and Q. In this case the LIL inventory of the primitive mantle is largely contained in MORB, $Q$, clinopyroxene, and CRUST. The results are: olivine, $33.0 \%$; orthopyroxene, $48.7 \%$; clinopyroxene, $3.7 \%$; MORB, $14.0 \% ; \mathrm{Q}, 0.085 \%$; and CRUST, $0.555 \%$.

Concentrations of certain key elements are: $\mathrm{Na} 2994$ ppm, K $205 \mathrm{ppm}$, Rb $0.53 \mathrm{ppm}$, Sr $25 \mathrm{ppm}$, and Cs 0.02 ppm. These can be compared with the previous results (Table 1): Na 2040, K 151, Rb 0.39, Sr 16, and Cs 0.02. 
TABLE 4. Elemental Ratios

\begin{tabular}{|c|c|c|c|c|c|c|c|c|}
\hline & \multirow[t]{2}{*}{$\mathrm{C} 1$} & \multirow{2}{*}{$\begin{array}{r}\text { MORGAN \& } \\
\text { ANDERS } \\
\end{array}$} & \multirow[t]{2}{*}{ UDS } & \multirow{2}{*}{$\begin{array}{c}\text { UPPER } \\
\text { MANTLE }\end{array}$} & \multirow{2}{*}{$\begin{array}{c}\text { LOWER } \\
\text { MANTLE }\end{array}$} & \multirow{2}{*}{$\begin{array}{l}\text { MANTLE } \\
\& \text { CRUST }\end{array}$} & \multicolumn{2}{|c|}{ NORMALIZED } \\
\hline & & & & & & & M\&A & $\mathrm{C} 1$ \\
\hline $\mathrm{Rb} / \mathrm{Sr}$ & 0.3026 & 0.0395 & 0.0304 & 0.0281 & 0.0101 & 0.024 & 0.61 & 0.08 \\
\hline $\mathrm{K} / \mathrm{U}$ & 63571 & 10000 & 11429 & 8356 & 3552 & 7693 & 0.77 & 0.12 \\
\hline $\mathrm{Sm} / \mathrm{Nd}$ & 0.3249 & 0.3297 & 0.315 & 0.319 & 0.318 & 0.319 & 0.97 & 0.98 \\
\hline $\mathrm{Th} / \mathrm{U}$ & 3.64 & 4.01 & 4.08 & 3.94 & 3.62 & 3.90 & 0.97 & 1.07 \\
\hline $\mathrm{U} / \mathrm{Pb}$ & 0.0039 & 0.20 & 0.20 & 0.17 & 0.13 & 0.16 & 0.82 & 42 \\
\hline $\mathrm{La} / \mathrm{Yb}$ & 1.48 & 1.66 & 2.18 & 1.85 & 1.43 & 1.77 & 1.07 & 1.20 \\
\hline $\mathrm{K} / \mathrm{Na}$ & 0.11 & 0.11 & 0.10 & 0.08 & 0.04 & 0.07 & 0.69 & 0.66 \\
\hline $\mathrm{Mg} / \mathrm{Si}$ & 0.90 & 0.92 & 0.43 & 0.84 & 0.95 & 0.92 & 1.00 & 1.01 \\
\hline $\mathrm{Ca} / \mathrm{Al}$ & 1.08 & 1.09 & 0.99 & 1.07 & 1.12 & 1.09 & 1.00 & 1.01 \\
\hline $\mathrm{Yb} / \mathrm{Sc}$ & 0.032 & 0.024 & 0.054 & 0.04 & 0.007 & 0.021 & 0.87 & 0.65 \\
\hline $\mathrm{Ce} / \mathrm{Nd}$ & 1.35 & 1.46 & 1.37 & 1.35 & 1.49 & 1.37 & 0.94 & 1.02 \\
\hline $\mathrm{Eu} / \mathrm{Nd}$ & 0.12 & 0.11 & 0.12 & 0.13 & 0.13 & 0.13 & 1.10 & 1.03 \\
\hline $\mathrm{Yb} / \mathrm{Lu}$ & 6.53 & 5.87 & 6.26 & 6.10 & 4.77 & 5.80 & 0.99 & 0.89 \\
\hline $\mathrm{Sr} / \mathrm{Ba}$ & 3.17 & 2.90 & 3.17 & 3.14 & 2.99 & 3.11 & 1.07 & 0.98 \\
\hline $\mathrm{U} / \mathrm{La}$ & 0.038 & 0.036 & 0.03 & 0.035 & 0.032 & 0.034 & 0.97 & 0.90 \\
\hline
\end{tabular}

The alkalies are generally within $50 \%$ of the concentrations determined previously. Key ratios are $\mathrm{Rb} / \mathrm{Sr} 0.021, \mathrm{~K} / \mathrm{U}$ 4323 , and $\mathrm{K} / \mathrm{Na} 0.07$. The $\mathrm{Rb} / \mathrm{Sr}$ and $\mathrm{K} / \mathrm{Na}$ ratios are essentially the same as those determined previously; the $\mathrm{K} / \mathrm{U}$ ratio is $44 \%$ lower.

\section{Mantle Reservoirs}

In the mantle evolution model of Anderson [1981, $1982 a, b]$, the upper and lower mantles are complementary products of early terrestrial differentiation. The lower mantle is the crystalline residue left after melt extraction rather than primitive, undifferentiated material as in some recent models. The upper mantle is divided into a shallow LILand olivine-rich peridotite layer and an eclogite transition region, which is the depleted (MORB) reservoir [Anderson, 1979]. Such a stratigraphy would result, for example, from the crystallization of a magma ocean. The lower mantle differs from the upper mantle in major element chemistry and intrinsic density and is isolated. The major phase is perovskite. Subduction of material into the lower mantle is prevented because of the broad stability field of garnet in $\mathrm{Al}_{2} \mathrm{O}_{3}$-rich silicates and the lower density of perovskite in $\mathrm{CaO}$ and $\mathrm{Al}_{2} \mathrm{O}_{3}$-rich eclogite. The temperature variations in the mantle are not great enough to allow density reversals, and therefore interchange of material, across the $650 \mathrm{~km}$ discontinuity.

On the other hand, the density contrast between the peridotite shallow mantle and the eclogite-rich transition region can be overcome if temperatures in the latter rise above the solidus. One mechanism for initiating melting is continental insulation [Anderson, 1982b]. The large density contrast associated with partial melting of eclogite and the narrow melting interval of eclogite means that diapirs from the transition region can rise rapidly and melt extensively as they traverse the peridotite layer. If trapped beneath thick lithosphere, these depleted magmas from the MORB reservoir can fractionate and mix with melts from the LIL-rich shallow mantle. Ocean island and continental flood basalts, in this scenario, are fractionated and contaminated MORB. from recent seismic data indicating that the East Pacific Rise extends to a depth of $400 \mathrm{~km}$ [Grand and Helmberger, 1983; Walck, 1982; Anderson and Regan, 1983]. An eclogite-rich transition region [Anderson, 1979] is also strongly supported by seismic data (Bass and Anderson, unpublished data, 1983).

In the context of the present chemical model the shallow mantle is mainly UMR plus Q; the transition region is mainly picrite (garnet plus clinopyroxene plus minor olivine); and the lower mantle is mainly orthopyroxene. UDS, in the eclogite model, is the MORB reservoir prior to depletion by removal of CRUST and Q. In a peridotite model UDS is the fusible component of the undifferentiated ('fertile') upper mantle. Differences in major element chemistry, and therefore intrinsic density, keep the reservoirs isolated. In the present thermal region the lower mantle is well below the melting point, but the density contrast between peridotite and eclogite, or 'fertile' peridotite, can be reversed by partial melting in the deeper layer.

Although there may be more than two isotopically distinct reservoirs providing basalts to the earth's surface, the spread and scatter of LIL and isotopic ratios can be largely explained by a combination of crystal fractionation of MORB and variable amounts of $Q$ contamination (Anderson, unpublished data, 1983).

\section{The Core}

In obtaining estimates for the composition of the mantle we have used cosmochemical estimates of refractory element ratios. The absolute levels can be combined with $\mathrm{M} \& \mathrm{~A}$ and $\mathrm{C} 1$ to estimate the composition of the core. The core is mainly $\mathrm{Fe}, \mathrm{Ni}, \mathrm{Co}$, and $\mathrm{S}$, but the total complement of these elements falls short of the $32.5 \mathrm{wt} \%$ required to form the core. As shown in Table 5, if the core contains $7.7 \%$ of oxygen, then the earth can have an overall composition (exclusive of volatiles) similar to carbonaceous chondrites. In the M\&A model there is an enrichment of $\mathrm{Fe}$ and $\mathrm{Ni}$ relative to silicates, and only $2.7 \%$ oxygen is required to bring the core up to the proper mass ratio with

A transition zone source for MORB has received support the mantle. The sulfur content of both M\&A and C1 type 
TABLE 5. Composition of Core

\begin{tabular}{llrr}
\hline & & $(1)$ & $(2)$ \\
\hline $\mathrm{Fe}$ & pct & 86.2 & 71.1 \\
$\mathrm{Ni}$ & pct & 5.2 & 4.3 \\
$\mathrm{Co}$ & pct & 0.2 & 0.2 \\
$\mathbf{P}$ & pct & 0.5 & 0.2 \\
$\mathrm{~S}$ & pct & 4.5 & 5.9 \\
0 & pct & 2.7 & 7.7 \\
$\mathrm{Cr}$ & ppm & 0.8 & \\
$\mathrm{Ge}$ & ppm & 21 & 0.6 \\
$\mathrm{Ga}$ & ppm & 0.6 & 143 \\
$\mathrm{Au}$ & ppm & 0.8 & 34 \\
$\mathrm{Ag}$ & ppm & 0.1 & 0.8 \\
$\mathrm{Re}$ & ppm & 0.2 & 0.8 \\
$\mathrm{Os}$ & ppm & 2.7 & 0.2 \\
$\mathrm{Ir}$ & ppm & 2.6 & 2.9 \\
\hline
\end{tabular}

(1) Morgan and Anders minus 'Mantle plus Crust.'

(2) $\mathrm{Cl}$ minus 'Mantle plus Crust.'

models is uncertain, and this trades off with the inferred oxygen content of the core.

\section{Conclusions}

It is commonly assumed that the earth should have chondritic ratios of the refractory elements. REE contents of basalts are generally normalized against chondritic abundances, and one speaks of LREE-enriched and -depleted basalts. Isotopic results are also commonly compared with chondritic ratios, and one speaks of depleted, less depleted, primitive, and enriched reservoirs. The need for an enriched reservoir, in addition to the continental crust, has recently become evident and is required, as in the present study, if mass balance is attempted for a large number of elements. Not only is kimberlite the most enriched mantle component, but it bears a melt-solid equilibrium relationship with MORB. Magmas of intermediate composition can be modeled as mixtures of MORB, or fractionated MORB, and kimberlite. We therefore argue that kimberlite can be identified as the enriched, or $Q$, component of the mantle. Kimberlite may play a role in manthe evolution similar to the role KREEP plays in lunar evolution. In any case, kimberlite is a component of the manthe and, because of the high LIL-concentrations and ${ }^{87} \mathrm{Sr} /{ }^{86} \mathrm{Sr}$ and ${ }^{144} \mathrm{Nd} /{ }^{143} \mathrm{Nd}$ ratios, must be allowed for in any LIL inventory of the mantle.

We have introduced a formalism for estimating the volatile content of the mantle that avoids the assumption that volatile/refractory ratios in the primitive mantle are the same as in the crust.

A four-component (crust, basalt, peridotite, and Q) model for the upper mantle has been derived that is based on chondritic ratios for the refractory trace elements. The ponent as UMR (Ultra-Mafic Rock). The second, more model gives predictions for volatile/refractory ratios such as opx-rich component (OPX) is depleted in $\mathrm{Ca}, \mathrm{Al}$, and LIL $\mathrm{K} / \mathrm{U}, \mathrm{Rb} / \mathrm{Sr}$, and $\mathrm{Pb} / \mathrm{U}$. An orthopyroxene-rich component relative to UMR and has about $20 \%$ more opx. The comis required in order to match chondritic ratios of the major patible trace elements are the same as UMR unless orthopyelements. Such a component is found in the upper mantle roxene has a different composition (e.g., $\mathrm{Sc}, \mathrm{Ti}, \mathrm{V}, \mathrm{Cu}, \mathrm{Zn}$, and is implied by the seismic data for the lower mantle. Ga, Se). The very incompatible elements are assumed to
The abundances in the mantle plus crust system are 152 ppm K, $0.0197 \mathrm{ppm} \mathrm{U}$, and $0.0766 \mathrm{ppm}$ Th, giving a steady-state heat flow of $0.9 \mu \mathrm{cal} / \mathrm{cm}^{2} \mathrm{~s}$. This implies that slightly more than one half of the terrestrial heat flow is due to cooling of the earth, which is consistent with convection calculations on a stratified earth [McKenzie and Richter, 1981].

The major and compatible trace element chemistry of the upper mantle is similar to previous two-component (basalt plus peridotite) models [Ringwood and Kesson, 1977], and the basalt:peridotite ratio is similar to pyrolite. There is therefore petrological support for the present model. There is no particular reason for supposing, however, that the whole mantle has this composition. Cosmochemical and seismological arguments favor a pyroxene-rich lower mantle.

\section{Appendix 1 - Compositions of Components}

\section{Basalt and $Q$}

Following Anderson [1982a,b, 1983] we decompose basalt into a depleted component (MORB) and an enriched component (Q). The composition of MORB is from Batiza and Johnson [1980], Engel et al. [1965], Kay and Hubbard [1978], Wolf and Anders [1980], and Hertogen et al. [1980]. For Q we use kimberlite analyses from Wederpohl and Muramatsu [1979] and Kramers et al. [1981]. Figure 1 shows that basalts of intermediate composition can be modeled as mixtures of MORB and kimberlite.

$\mathrm{Q}$ is short for 'quintessence,' literally the fifth essence or element (quintessential), which is defined as the pure and concentrated essence of a substance. The essential components of the mantle, then, are olivine, orthopyroxene, clinopyroxene, garnet, and a fifth essence, $Q$.

Kimberlite, the terrestrial analog of KREEP, not only is the most LIL-rich mantle component but also represents an extreme in $\mathrm{Sr}$ and $\mathrm{Nd}$ isotopic composition [McCulloch et al., 19831.

\section{Ultramafic Rocks (UMR and OPX)}

In order not to prejudge the major element chemistry of the mantle, we need two ultramafic components with different ol/opx ratios. One could choose dunite and orthopyroxenite, which would represent end members, or two different rock types of intermediate composition. In the main part of the present paper we adopt, as one component, a less extreme (more 'primitive') ultramafic rock in order to highlight differences with Wänke [1981], Jagoutz et al. [1979], and Ringwood and Kesson [1977]. For the olivinerich component (UMR), we use data from Jagoutz et al. [1979], Wederpohl and Muramatsu [1979], and Philpotts et al. [1972] for 'primitive' or average ultramafic rocks. This is not an end member since it contains a basaltic and a $Q$ component as well as ol and opx. We refer to this comincompatible elements are assumed to 
have negligible concentrations. The moderately incompatible elements are reduced from UMR by various factors using rock and mineral analyses from Wederpohl and Muramatsu [1979], Philpotts et al. [1972], Frey [1982], and Basaltic Volcanism Study Project [1981]. The REE are similar to Frey's most depleted peridotite. In the mass balance for most of the incompatible trace refractories, the compositions of UMR and OPX are essentially irrelevant.

\section{Crust}

We use data from Taylor [1982] and Mason [1966] for the composition of the continental crust. We adopt the value of $0.555 \%$ for the mass of the crust relative to the mantle. The $\mathrm{Cl}$ content of seawater is included in the crustal composition.

\section{Cosmochemical Normalizations}

The carbonaceous chondrite $(\mathrm{C} 1)$ values are from Taylor [1982] and Anders and Ebihara [1982]. The Morgan and Anders [1980] model is for mantle, crust, and core. We have slightly revised their estimates for $\mathrm{S}, \mathrm{Sr}, \mathrm{Nb}, \mathrm{Sm}, \mathrm{U}$, and $\mathrm{Th}$. When normalizing to their results we use the factor 1.48 to convert from 'terrestrial' to 'mantle' abundances so that oxyphile elements can be directly compared.

The values in Tables 1 and 3, excluding the ratios in the last two columns of Table 3, are in ppm except for $\mathrm{Na}, \mathrm{Mg}$, $\mathrm{Al}, \mathrm{Si}, \mathrm{Ca}$, and $\mathrm{Fe}$ (percent) and $\mathrm{Tl}, \mathrm{Ir}, \mathrm{Os}, \mathrm{Re}$, and $\mathrm{Au}$ (ppb).

Acknowledgments. I would like to thank Jay Bass, John Philpotts, John Morgan, and Robin Brett for extremely useful reviews. This research was supported by National Science Foundation grant EAR 81-15236. This paper is contribution number 3858, Division of Geological and Planetary Sciences, California Institute of Technology, Pasadena, California 91125.

\section{References}

Anders, E., and M. Ebihara, Solar-system abundances of the elements, Geochim. Cosmochim. Acta, in press, 1983.

Anderson, Don L., Petrology of the mantle, Mineral. Soc. Am. Spec. Paper, 3, 85, 1970.

Anderson, Don L., Composition of the mantle and core, Ann. Rev. Earth Planet. Sci., 5, 179, 1977.

Anderson, Don L., The upper mantle transition region: eclogite?, Geophys. Res. Lett., 6, 433, 1979.

Anderson, Don L., Hotspots, basalts and the evolution of the mantle, Science, 23, 82, 1981.

Anderson, Don. L, Isotopic evolution of the mantle, Earth Planet. Sci. Lett., 57, 1, $1982 a$.

Anderson, Don L., Chemical composition and evolution of the mantle, Adv. Earth Planet. Sci., 12, 301-318, $1982 b$.

Anderson, Don $\mathrm{L}_{\circ}$, Kimberlite and the evolution of the mantle, Proc. Third Intl. Kimberlite Conference, Clermont-Ferrand, France, in press, 1983.

Anderson, Don L., and J. Regan, Anisotropy and the oceanic lithosphere, Geophys. Res. Lett., in press, 1983.

Basaltic Volcanism Study Project, Basaltic Volcanism on the Terrestrial Planets, Pergamon, New York, 1286 pp., 1981.

Basu, A., and M. Tatsumoto, Nd-isotopes in selected mantlederived rocks and minerals, Contrib. Mineral. Petrol., 75, 43, 1980.

Batiza, R., and J. Johnson, Trace element and isotopic evidence for magma mixing, Initial Reports Deep Sea Drilling Project LIV, 63, 1980 :

Berg, G., and H. Allsop, Low ${ }^{87} \mathrm{Sr} /{ }^{86} \mathrm{Sr}$ ratios in fresh S. African kimberlites, Earth Planet. Sci. Lett., 16, 27, 1972.
Birch, F., Composition of the earth's mantle, Geophys. J., 4, 295, 1961.

Burdick, L., and Don L. Anderson, Interpretations of velocity profiles, J. Geophys. Res., 80, 1070, 1975.

Butler, R., and Don L. Anderson, Equation of state fits to the lower mantle, Phys. Earth Planet. Inter., 17, 147, 1978.

Carlson, R., G. W. Lugmair, and J. Macdougall, Columbia River Volcanism, Geochim. Cosmochim. Acta, 45, 2483, 1981.

Chen, C.-Y., and F. Frey, Origin of Hawaiian tholeiite and alkali basalt, Nature, 302, 785, 1983.

Davies, G., Limits on the constitution of the lower mantle, Geophys. J. R. Astron. Soc., 38, 479, 1974.

DePaolo, D. J., and G. J. Wasserburg, Neodymium isotopes in flood basalts from the Siberian Platform, Proc. Nat. Acad. Sci., 76, 3056, 1979.

Engel, A., C. Engel, and R. Havens, Chemical characteristics of oceanic basalts and the upper mantle, Geol. Soc. Am. Bull., 76, $719,1965$.

Frey, F., Rare earth element abundances in upper mantle rocks, in Rare Element Geochemistry, edited by P. Henderson, Elsevier, New York, in press, 1982.

Gast, P., The chemical composition of the Earth, Moon and chondritic meteorites, in The Nature of the Solid Earth, edited by E. C. Robertson, p. 19, McGraw-Hill, New York, 1972.

Grand, S., and D. V. Helmberger, Upper mantle shear structure of North America, J. Geophys. Res., in press, 1983.

Green, D., W. Hibberson, and A. Jaques, Petrogenesis of midocean ridge basalts, in The Earth: Its Origin, Structure and Evolution, edited by N. W. McElhinney, pp. 265-299, Academic, New York, 1979.

Hawkesworth, C., and R. Vollmer, Crustal contamination vs. enriched mantle, Contrib. Mineral. Petrol., 69, 151, 1979.

Hertogen, J., M. J. Janssens, and H. Palme, Trace elements in ocean ridge basalt glasses, Geochim. Cosmochim. Acta, 44, 2125, 1980.

Jagoutz, E., H. Palme, H. Buddenhausen, K. K. Blum, M. Cendales, G. Driebus, B. Spettel, V. Lorenz, and H. Wänke, The abundances of major, minor and trace elements in the earth's mantle as derived from primitive ultramafic nodules, Proc. Lunar Planet. Sci. Conf. 10th, 2031, 1979.

Kay, R., and N. Hubbard, Trace elements in ocean ridge basalts, Earth Planet. Sci. Lett., 38, 95, 1978.

Kramers, J., C. Smith, N. Lock, R. Harmons, and F. Boyd, Can kimberlite be generated from ordinary mantle?, Nature, 291, 53, 1981.

Liebermann, R., A. Ringwood, and A. Major, Elasticity of polycrystalline stishovite, Earth Planet. Sci. Lett., 32, $127,1976$.

Liu, L., Silicate perovskite from phase transformation of pyrope garnet, Geophys. Res. Lett., 1, 277, 1974.

Mason, B., Principles of Geochemistry, Third Edition, Wiley and Sons, New York, 329 pp., 1966.

McCulloch, M. T., R. Arculus, B. Anappell, and J. Ferguson, Isotopic and geochemical studies of nodules in kimberlites, Nature, $300,166,1982$.

McCulloch, M. T., A. Jaques, D. Nelson, and J. Lewis, Nd and Sr isotopes in kimberlites and lamproites from Western Australia: An enriched mantle origin, Nature, 302, 400, 1983.

McKenzie, D., and F. Richter, Parameterized thermal convection in a layered region, J. Geophys. Res., 86, 11,667, 1981.

Menzies, M., W. P. Leeman, and C. Hawkesworth, Isotope geochemistry of Cenozoic volcanic rocks reveals mantle heterogeneity below western USA, Nature, 303, 205, 1983.

Menzies, M., and V. R. Murthy, Enriched mantle: Nd and $\mathrm{Sr}$ isotopes, Nature, 283, 634, 1980.

Morgan, J. W., and E. Anders, Chemical composition of Earth, Venus and Mercury, Proc. Natl. Acad. Sci., 77, 6973, 1980.

Philpotts, J., C. C. Schnetzler, and H. H. Thomas, Petrogenetic implications of some new geochemical data on eclogitic and ultrabasic inclusions, Geochim. Cosmochim. Acta, 36, 1131, 1972.

Press, F., Earth models consistent with geophysical data, Phys. Earth Planet. Inter., 3, 3, 1970.

Ringwood, A., Composition and Petrology of the Earth's Mantle, McGraw-Hill, New York, 618 pp., 1975.

Ringwood, A., Origin of the Earth and Moon, Springer-Verlag, New York, 295 pp., 1979. 
Ringwood, A. E., and S. Kesson, Siderophile and volatile elements in Moon, Earth and chondrites, Moon, 16, 425, 1977.

Taylor, S., Lunar and terrestrial crusts, Phys. Earth Planet. Inter., $29,233,1982$

Walck, M., Models of upper mantle compressional velocity under a spreading center, Eos Trans. AGU, 63, 1036, 1982.

Wänke, H., Constitution of the terrestrial planets, Phil. Trans. $R$. Soc. Lond., A303, 287, 1981.

Watt, J. P., and T. Ahrens, The role of iron partitioning in mantle composition, evolution and scale of convection, J. Geophys. Res. $87,5631,1982$.

Watt, P., and R. O'Connell, Mixed-oxide and perovskite-structure model mantles from $700-1200 \mathrm{~km}$, Geophys. J. R. Astron. Soc., $54,601,1978$.

Wederpohl, K. H., and Y. Muramatsu, The chemical composition of kimberlites compared with the average composition of three basaltic magma types, in Kimberlite, Diatremes and Diamonds, edited by F. R. Boyd and H. O. Meyer, 300 pp., Am. Geophys. Union, 1979.

Weidner, D., J. D. Bass, A. E. Ringwood, and W. Sinclair, The single-crystal elastic moduli of stishovite, J. Geophys. Res., 87, $4740,1982$.

Wolf, R., and E. Anders, Moon and Earth: compositional differences inferred from siderophiles, volatiles and alkalies in basalts, Geochim. Cosmochim. Acta, 44, 2111, 1980.

Yagi, T., H. Mao, and P. Bell, Isothermal compression of perovskite-type $\mathrm{MgSiO}_{3}$, Carnegie Inst. Wash. Yearb., 77, 835, 1978.

Yagi, T., H. Mao, and P. Bell, Isothermal compression of perovskite-type $\mathrm{MgSiO}_{3}$, Carnegie Inst. Wash. Yearb., 78, 613, 1979.

Don L. Anderson, Seismological Laboratory, California Institute of Technology, Pasadena, CA 91125.

(Received April 20, 1983;

revised August 16, 1983;

accepted August 26, 1983.) 